\section{SOI: $1.1 /$ TAS DOI: $10.15863 / \mathrm{T}$ Theoretical \& Applied Science}

\author{
p-ISSN: 2308-4944 (print) e-ISSN: 2409-0085 (online) \\ Year: 2017 Issue: 12 Volume: 56
}

Published: $25.12 .2017 \quad$ http://T-Science.org
Vladimir S. Osipov

Doctor in Economics

Plekhanov Russian University of Economics, Market Economy Institute of Russian Academy of Sciences, Lomonosov Moscow State University, All-Russian Research Institute of Potato farming by A.G. Lorh, Moscow, Russia

SECTION 31. Economic research, finance, innovation, risk management.

\title{
BASIC SOCIAL-ECONOMIC FACTORS OF FAR EASTERN DISTRICT DEVELOPMENT
}

\begin{abstract}
In the implementation of the projects of the territories of priority development (TPD), the factors of social-economic development have great importance. The article is based on a set of statistical data analysis of the social-economic factors in the regions of Far Eastern Federal District, the subjects of the federation, included in it, and in Russia as a whole. We analyzed the statistical data (pensions, benefits, levels of wages,) and the number of employees as one of the basic factor of production. On the basis of analyzed data were drawn conclusions on the insufficient provision of TPDs with a potential labor force, a negative migration balances, the need and at the same time, the undesirability of attracting foreign labor, as well as the factors of the rootedness of the workforce in the Far Eastern Federal District of Russian Federation

Key words: territory of priority development, social-economic factors, employment, wages, pensions, Far Eastern Federal District.

Language: English

Citation: Osipov VS (2017) BASIC SOCIAL-ECONOMIC FACTORS OF FAR EASTERN DISTRICT DEVELOPMENT. ISJ Theoretical \& Applied Science, 12 (56): 64-71.

Soi: http://s-o-i.org/1.1/TAS-12-56-13 Doi: crossef https://dx.doi.org/10.15863/TAS.2017.12.56.13
\end{abstract}

The reported study was funded by RFBR according to the research project № 16-02-00141

\section{Introduction}

When the Federal Law of December 29, 2014 No. 473-FZ "On the Territories of Priority Social and Economic Development in the Russian Federation" was adopted, it was already known that, although its effect was extended to the entire territory of the Russian Federation, all its focus was shifted to the subjects of the Far Eastern Federal District (FEFD) $[5,6,7]$. In accordance with the law, the Territory of Priority Development (TPD) is a part of the territory of a subject of the Russian Federation, including a closed administrative territorial entity, in which, in accordance with the decision of the Government of the Russian Federation, a special legal regime for the implementation of entrepreneurial and other activities is established with a view to creating favorable conditions for attracting investments, ensuring accelerated socio-economic development and creating comfortable conditions for ensuring the livelihoods of people.

\section{Materials and Methods}

It should be noted that one of the main goals of creating TPDs is to provide for accelerated socioeconomic development and create comfortable conditions for ensuring the vital activity of the population. To determine the directions for ensuring accelerated socio-economic development, it is necessary to consider the starting conditions of the social-economic situation in the Far Eastern Federal District [2,3]. As noted Charkina [10], the location of the region, its resource and industrial potential, highly skilled labor offer opportunities for the implementation of several TPD models reflecting the best world experience and current and prospective competitive advantages of the region. She and Skryl agree [9], while noting that in the implementation of the mechanism of territories of priority development, the labor factor plays the most important role.

The analysis of trends in the average monthly nominal payroll of employees for a full range of organizations in the economy as a whole in the Far Eastern Federal District and in the Russian 


\begin{tabular}{l|lr|ll|ll} 
& ISRA (India) & $=\mathbf{1 . 3 4 4}$ & SIS (USA) & $=\mathbf{0 . 9 1 2}$ & ICV (Poland) & $=\mathbf{6 . 6 3 0}$ \\
Impact Factor: & ISI (Dubai, UAE) $=\mathbf{0 . 8 2 9}$ & PUH (Russia) $=\mathbf{0 . 2 0 7}$ & PIF (India) & $=\mathbf{1 . 9 4 0}$ \\
& GIF (Australia) & $=\mathbf{0 . 5 6 4}$ & ESJI (KZ) & $=4.102$ & IBI (India) & $=\mathbf{4 . 2 6 0}$ \\
& JIF & $=\mathbf{1 . 5 0 0}$ & SJIF (Morocco) & $=2.031$ & & \\
\hline
\end{tabular}

Federation for the period 2000-2016 (Figure 1) allows us to conclude that for the whole analyzed period, wages in the Far Eastern Federal District grew faster than the average for Russia, and from year to year, the rate of growth in the Far Eastern Federal District is also higher than in Russia.

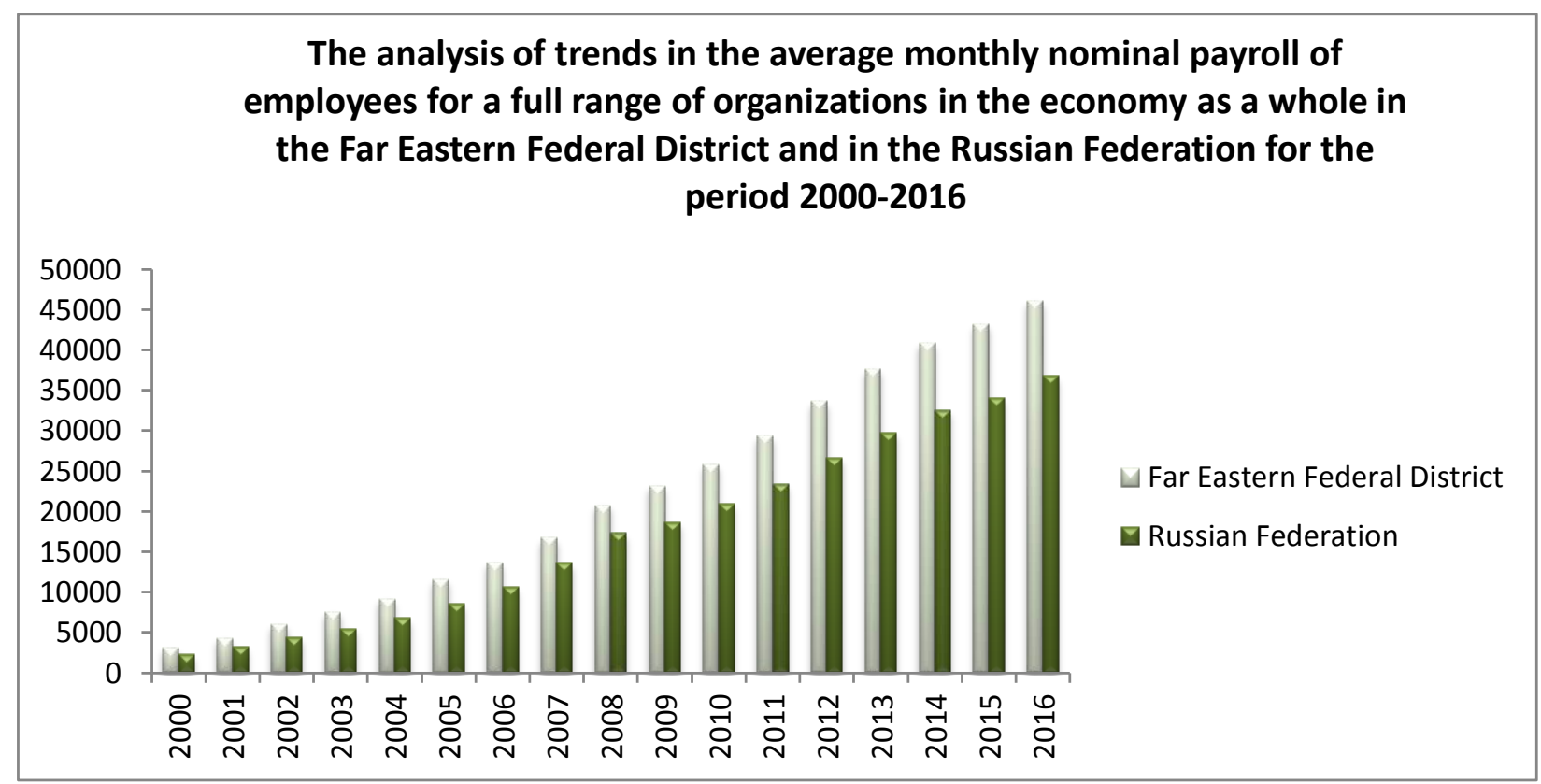

Figure 1 - The analysis of trends in the average monthly nominal payroll of employees for a full range of organizations in the economy as a whole in the Far Eastern Federal District and in the Russian Federation for the period 2000-2016

This situation can be explained by several reasons, among which there is a significant differentiation by types of economic activity (Figure 2 ). Thus, almost a twofold excess over the average value (36745.7 rubles.) Is observed by types of economic activity "Mining" (69688 rubles) and "Financial activities" (78311 rubles). Given the high importance of financial services and mining for the economy of the country (service and raw materials economy), it is obvious that such levels of wages are to some extent justified. Nonetheless, a multiple excess significantly affects the average level of wages; without taking into account the sectors of mining and financial activities, the average value of wages would be significantly lower, especially taking into account the number of workers in the low-paid social sphere. 


\begin{tabular}{|c|c|c|c|c|c|c|}
\hline Impact Factor: & $\begin{array}{l}\text { ISRA (India) } \\
\text { ISI (Dubai, UAB } \\
\text { GIF (Australia) } \\
\text { JIF }\end{array}$ & $\begin{array}{l}=1.344 \\
=0.829 \\
=0.564 \\
=1.500\end{array}$ & $\begin{array}{l}\text { SIS (USA) } \\
\text { PИHЦ (Russia) } \\
\text { ESJI (KZ) } \\
\text { SJIF (Morocco) }\end{array}$ & $\begin{array}{l}=0.912 \\
=0.207 \\
=4.102 \\
=\mathbf{2 . 0 3 1}\end{array}$ & $\begin{array}{l}\text { ICV (Poland) } \\
\text { PIF (India) } \\
\text { IBI (India) }\end{array}$ & $\begin{array}{l}=6.630 \\
=1.940 \\
=4.260\end{array}$ \\
\hline
\end{tabular}

\section{The average monthly nominal accrued wages of employees for a full range of organizations by types of economic activity in the Russian Federation for 2016}

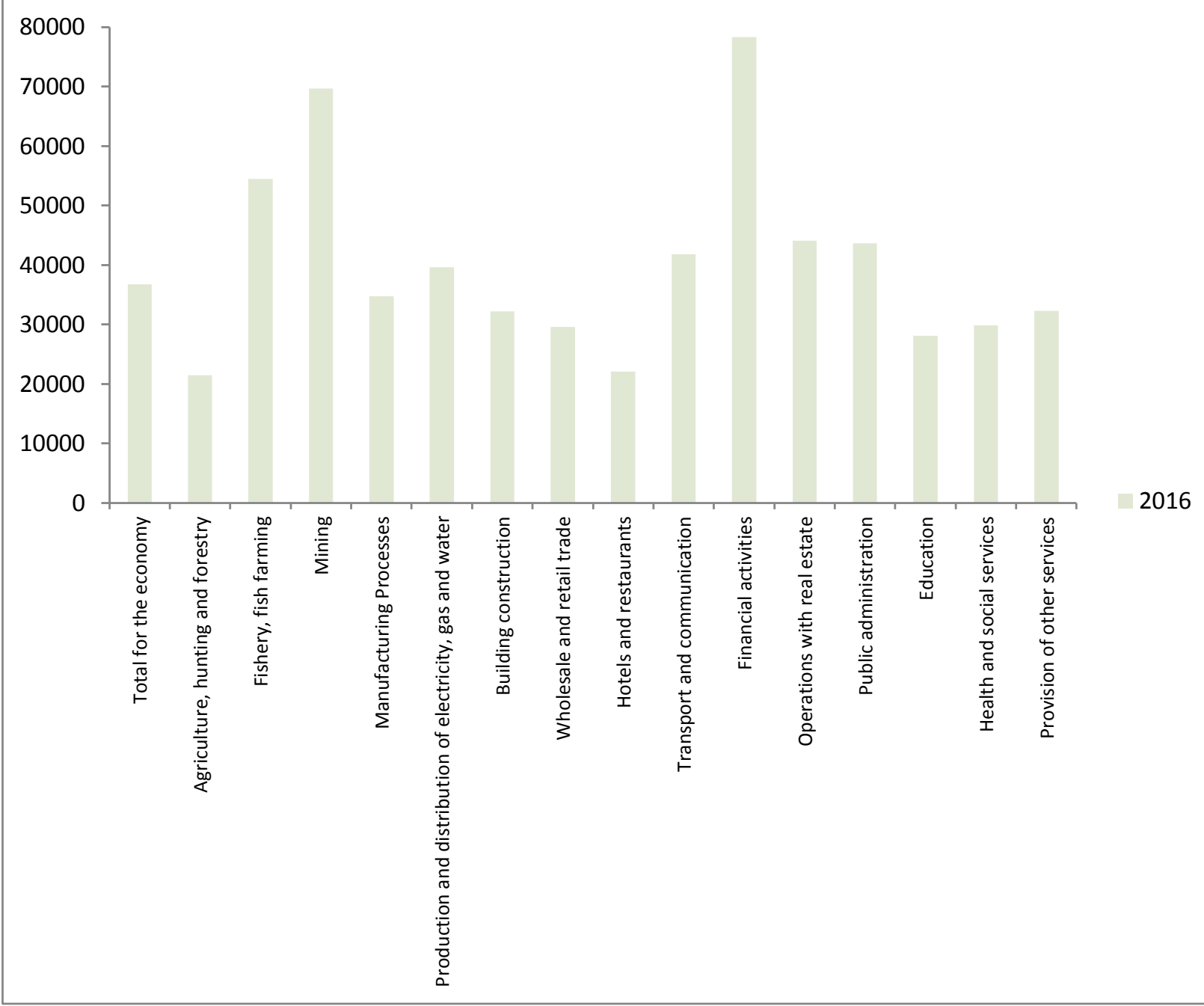

Figure 2 - The average monthly nominal accrued wages of employees for a full range of organizations by types of economic activity in the Russian Federation for 2016

An important factor in assessing the quality of the social sphere in the Far Eastern Federal District is the differentiation of salaries for the subjects of the federation that are members of the Far Eastern Federal District (Figure 3). 


\begin{tabular}{|c|c|c|c|c|c|c|}
\hline Impact Factor: & $\begin{array}{l}\text { ISRA (India) } \\
\text { ISI (Dubai, UAE } \\
\text { GIF (Australia) } \\
\text { JIF }\end{array}$ & $\begin{array}{l}=1.344 \\
=0.829 \\
=0.564 \\
=1.500\end{array}$ & $\begin{array}{l}\text { SIS (USA) } \\
\text { PИНЦ (Russia) } \\
\text { ESJI (KZ) } \\
\text { SJIF (Morocco) }\end{array}$ & $\begin{array}{l}=0.912 \\
=0.207 \\
=4.102 \\
=\mathbf{2 . 0 3 1}\end{array}$ & $\begin{array}{l}\text { ICV (Poland) } \\
\text { PIF (India) } \\
\text { IBI (India) }\end{array}$ & $\begin{array}{l}=6.630 \\
=1.940 \\
=4.260\end{array}$ \\
\hline
\end{tabular}

The average monthly nominal accrued wages of employees for a full range of organizations in the economy as a whole in the subjects of the Russian Federation of the Far Eastern Federal District for 2000-2016

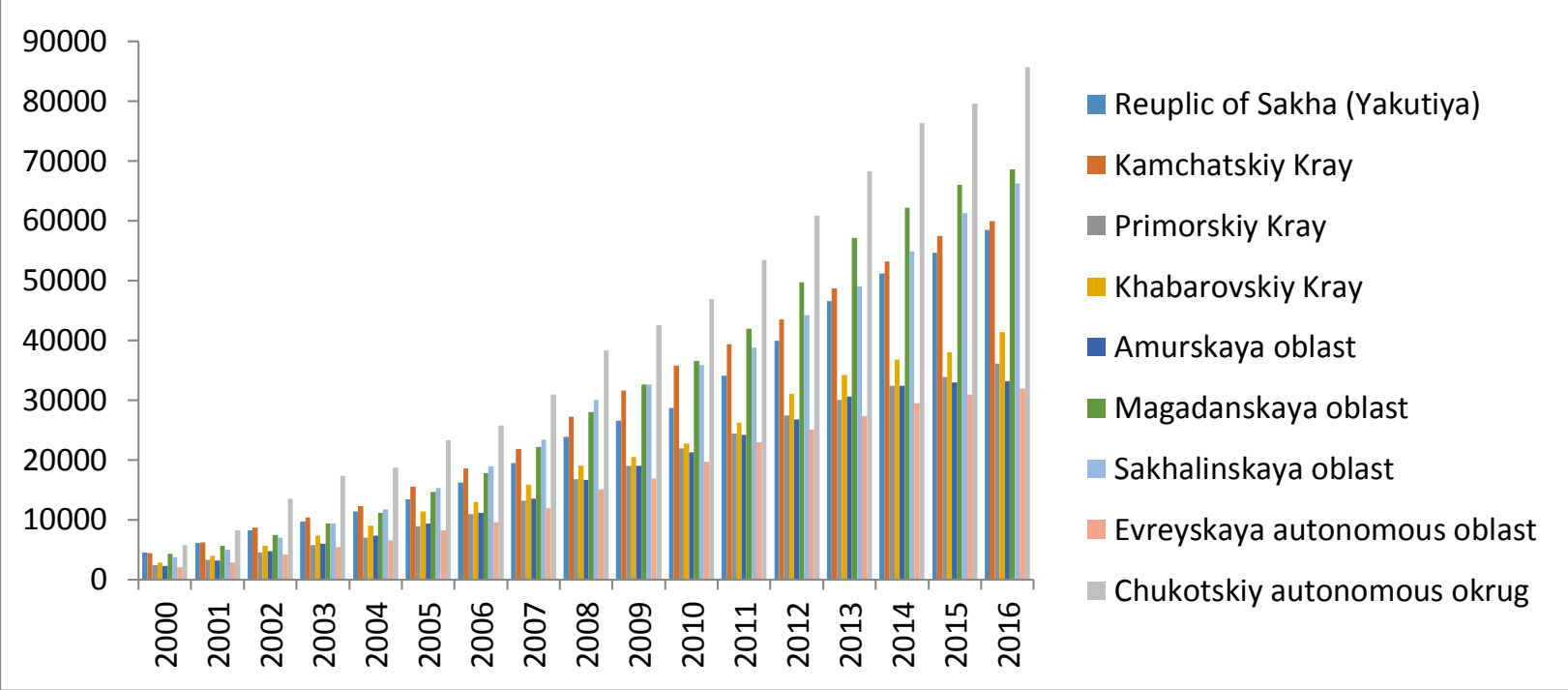

Figure 3 - The average monthly nominal accrued wages of employees for a full range of organizations in the economy as a whole in the subjects of the Russian Federation of the Far Eastern Federal District for 20002016.

As we can estimate, the Chukotskiy autonomous okrug, Magadanskaya and Sakhalinskaya oblast have a significant excess over other subjects of the Federation of the Far Eastern Federal District, where salaries were multiples higher than those of neighbors. The worst in this respect are the Evreyskaya autonomous oblast, the Amurskaya oblast and the Primorskiy Kray.

Let us now turn to the number of people working in the subjects of the Federation of the Far Eastern Federal District (Figure 4).

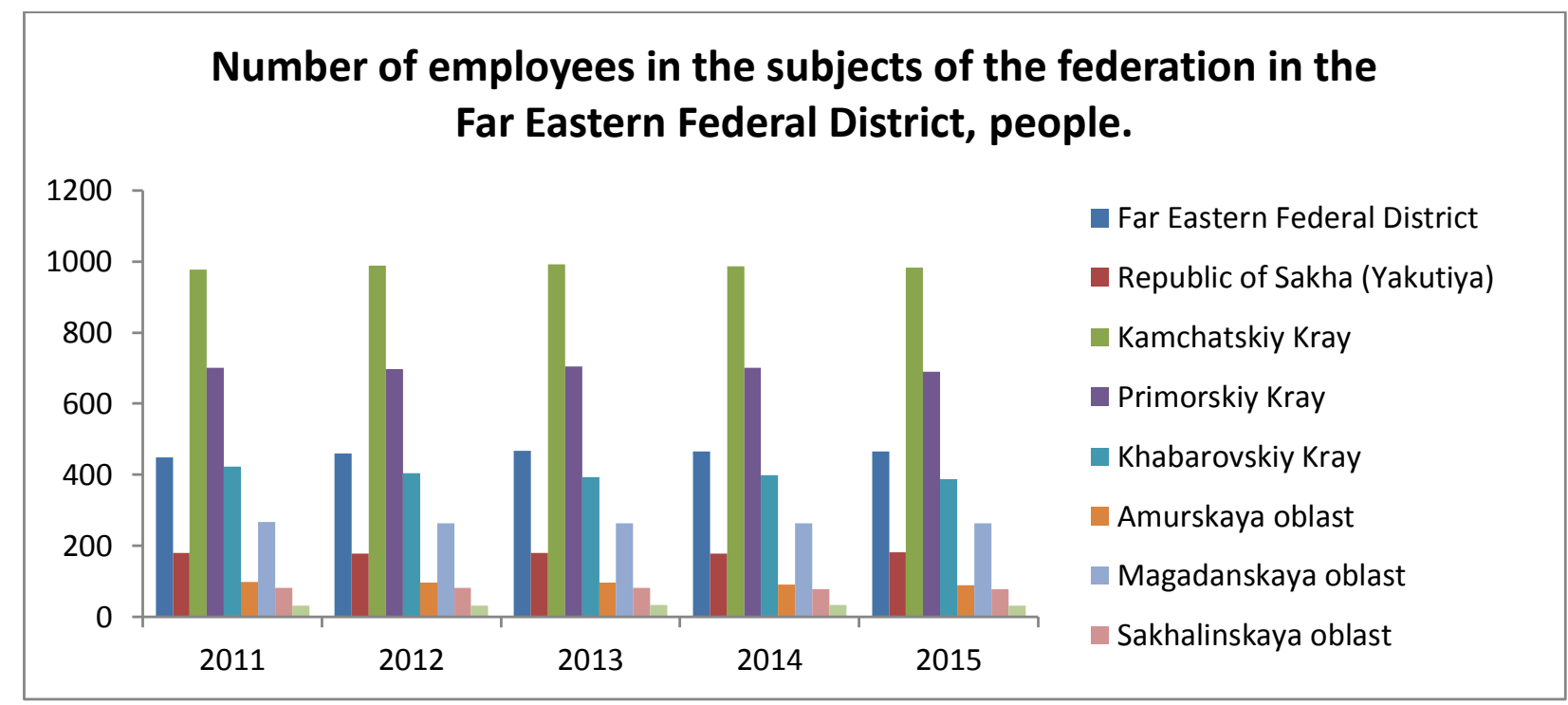

Figure 4 - Number of employees in the subjects of the federation in the Far Eastern Federal District, people 


\begin{tabular}{l|lr|ll|ll} 
& ISRA (India) & $=\mathbf{1 . 3 4 4}$ & SIS (USA) & $=\mathbf{0 . 9 1 2}$ & ICV (Poland) & $=\mathbf{6 . 6 3 0}$ \\
Impact Factor: & ISI (Dubai, UAE) $=\mathbf{0 . 8 2 9}$ & PUHЦ (Russia) $=\mathbf{0 . 2 0 7}$ & PIF (India) & $=\mathbf{1 . 9 4 0}$ \\
& GIF (Australia) & $\mathbf{0 . 5 6 4}$ & ESJI (KZ) & $=4.102$ & IBI (India) & $=\mathbf{4 . 2 6 0}$ \\
& JIF & $=\mathbf{1 . 5 0 0}$ & SJIF (Morocco) & $=\mathbf{2 . 0 3 1}$ & & \\
\hline
\end{tabular}

The minimal volume of population was in the Chukotskiy autonomous okrug and the Magadanskaya oblast, with the highest average monthly salary there. In the Primorsky Kray, the opposite situation is the highest supply of labor and one of the lowest average monthly accrued salaries.

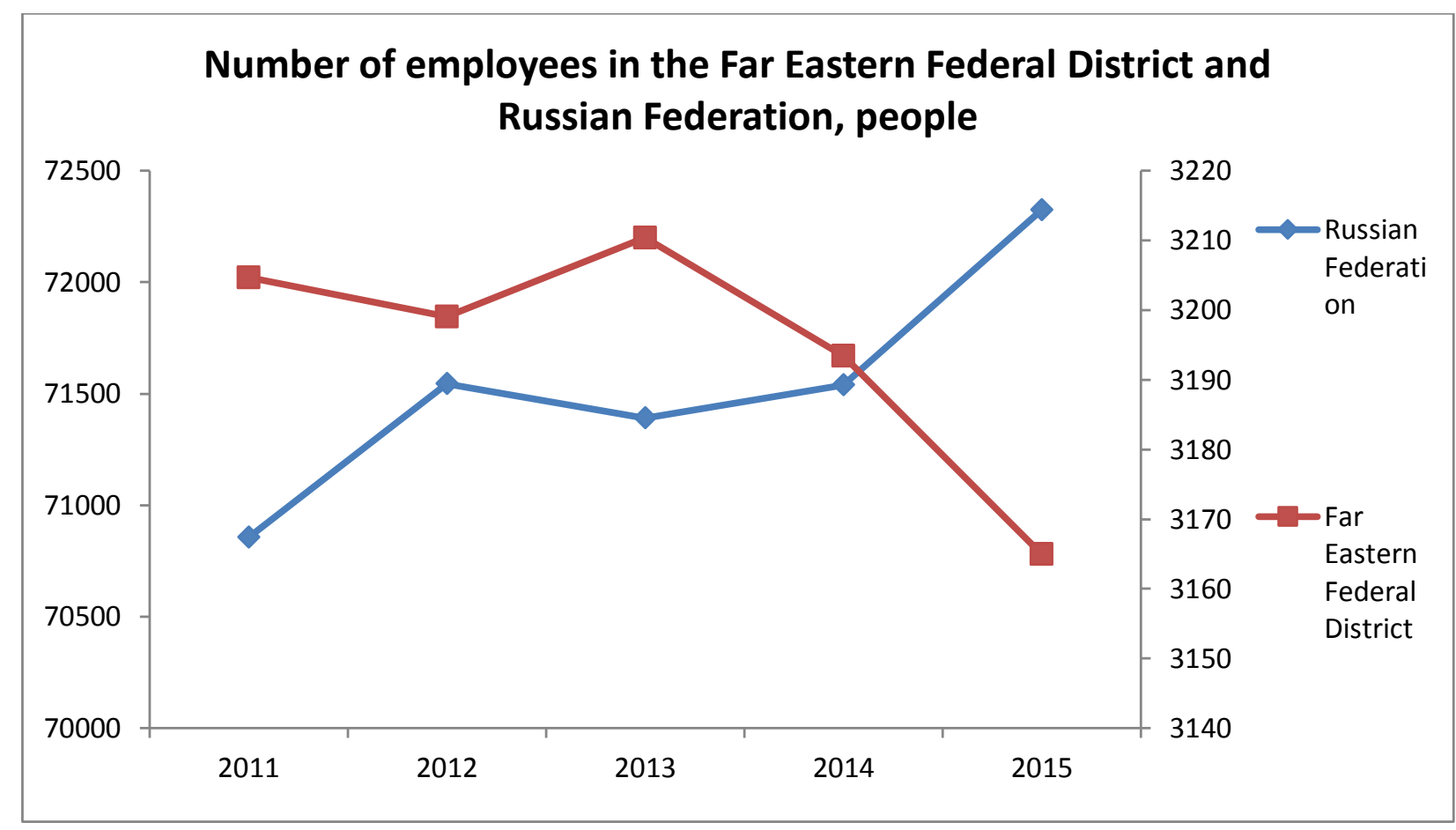

Figure 5 - Number of employees in the Far Eastern Federal District and Russian Federation, people

It is important to note that the number of employees in the Russian Federation and the Far Eastern Federal District have different trends. In the Far Eastern Federal District, the number of employed is declining, while in the Russian Federation it is increasing. One can explain this situation by the fact that the working population is trying to leave the
FEFD. If our assumption is correct, then the negative trend will continue, and the smoothing function (Figure 6) with a high level of the value of the reliability of the approximation $\left(R^{2}=0,8909\right)$ shows a further decrease in the number of employees for the next three years.

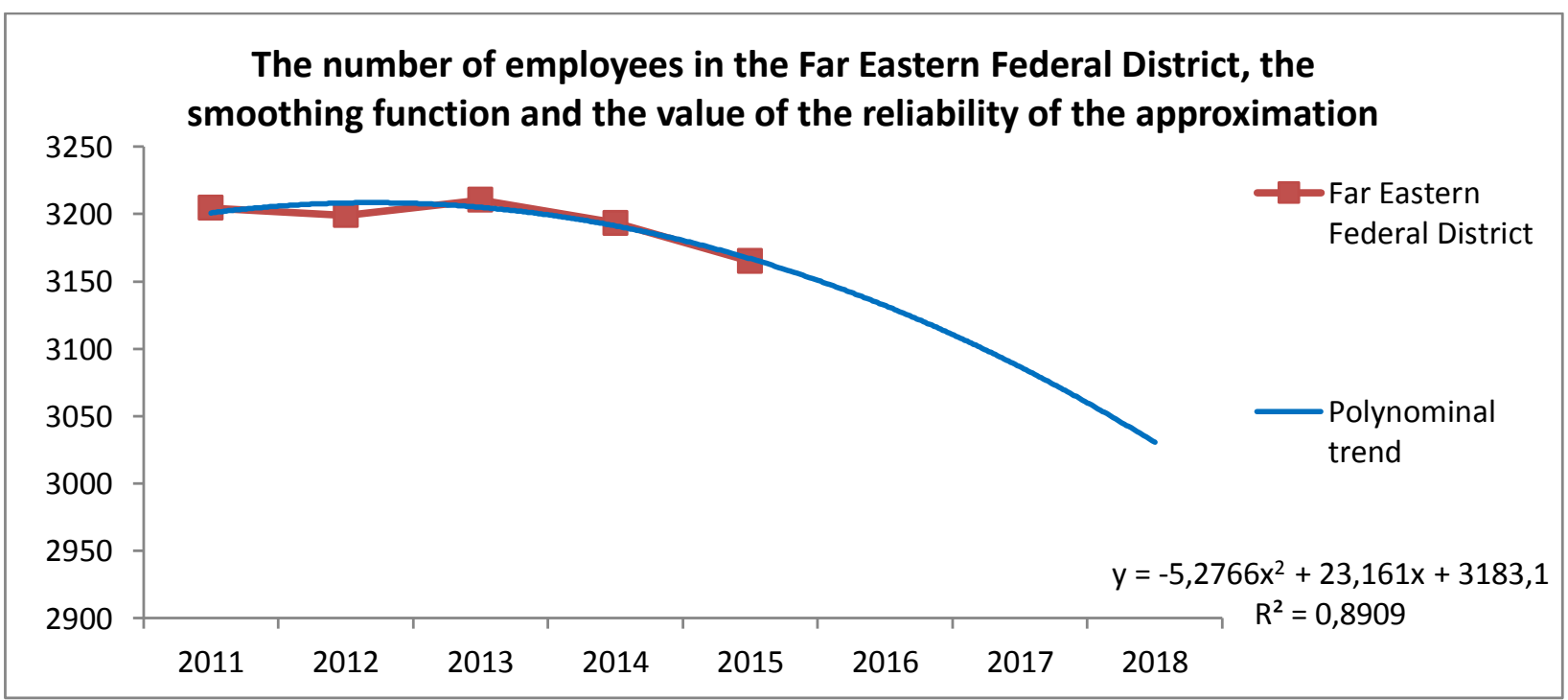

Figure 6 - The number of employees in the Far Eastern Federal District, the smoothing function and the value of the reliability of the approximation

ISPC Generalization of scientific results, 


\begin{tabular}{|c|c|c|c|c|c|c|}
\hline Impact Factor: & $\begin{array}{l}\text { ISRA (India) } \\
\text { ISI (Dubai, UAE } \\
\text { GIF (Australia) } \\
\text { JIF }\end{array}$ & $\begin{array}{r}=1.344 \\
=0.829 \\
=0.564 \\
=1.500\end{array}$ & $\begin{array}{l}\text { SIS (USA) } \\
\text { PИHЦ (Russia) } \\
\text { ESJI (KZ) } \\
\text { SJIF (Morocco) }\end{array}$ & $\begin{array}{l}=0.912 \\
=0.207 \\
=4.102 \\
=\mathbf{2 . 0 3 1}\end{array}$ & $\begin{array}{l}\text { ICV (Poland) } \\
\text { PIF (India) } \\
\text { IBI (India) }\end{array}$ & $\begin{array}{l}=6.630 \\
=1.940 \\
=4.260\end{array}$ \\
\hline
\end{tabular}

The pension provision is of great importance for the entrenchment of working citizens in the Far Eastern Federal District. Quite expected (Figure 7), but the size of pensions was in the Far Eastern Federal District as well as wages higher than the average for Russia.

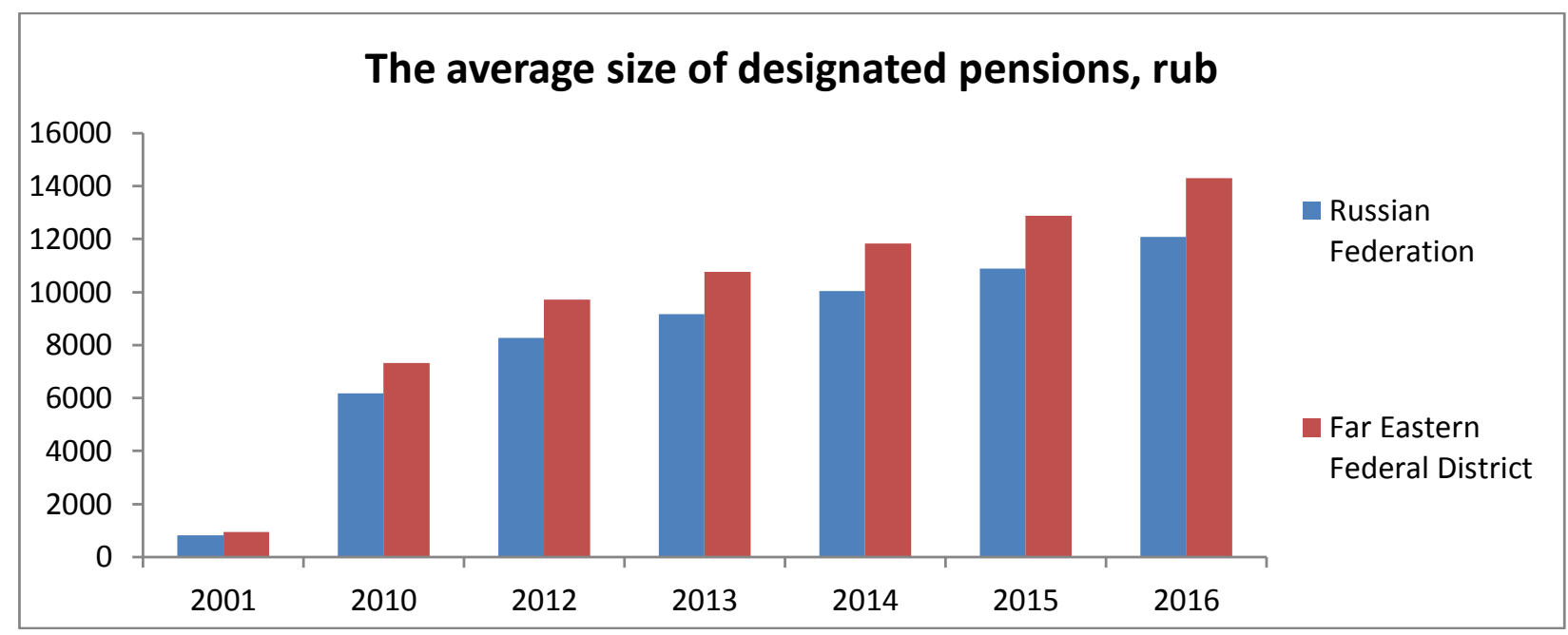

Figure 7 - The average size of designated pensions in the Russian Federation and in the Far Eastern Federal District

Inside the FEFD, the average size of designated pensions differs from subject to subject somewhat differently from average wages (Figure 8).

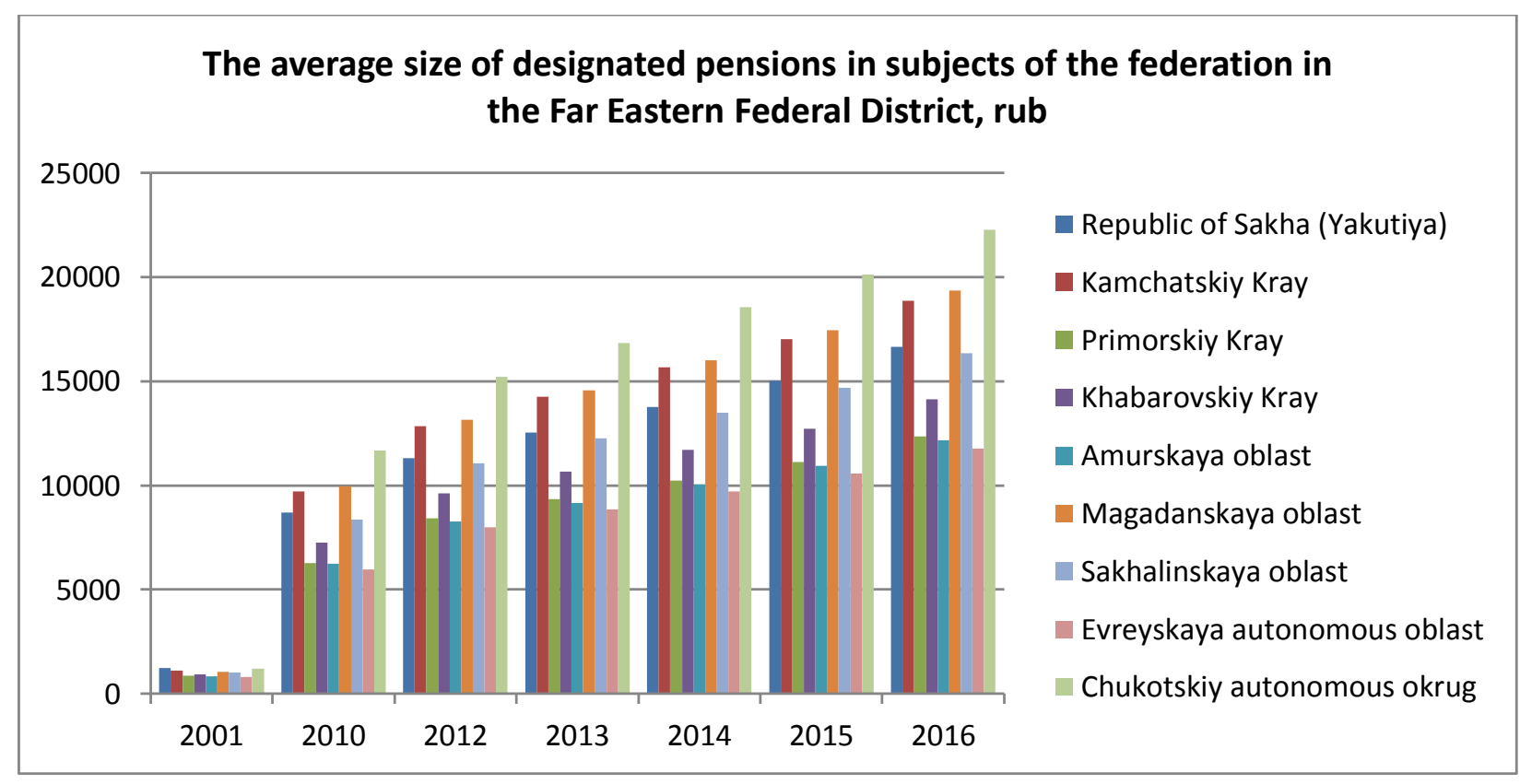

Figure 8 - The average size of designated pensions in the subjects of the Russian Federation of the Far Eastern Federal District

The highest amount of pensions assigned was in the Chukotskiy autonomous okrug, Magadanskaya oblast, Kamchatskiy Krai, the Republic of Sakha (Yakutia) and the Sakhalinskaya oblast, and the lowest in the Evreyskaya autonomous oblast and Amurskaya oblast and Primorskiy Krai. Low levels of pensions in the Evreyskaya autonomous oblast are explained by the lowest number of employees; and

ISPC Generalization of scientific results, 


\begin{tabular}{|c|c|c|c|c|c|c|}
\hline Impact Factor: & $\begin{array}{l}\text { ISRA (India) } \\
\text { ISI (Dubai, UAE } \\
\text { GIF (Australia) } \\
\text { JIF }\end{array}$ & $\begin{array}{l}=1.344 \\
=0.829 \\
=0.564 \\
=1.500\end{array}$ & $\begin{array}{l}\text { SIS (USA) } \\
\text { PИНЦ (Russia) } \\
\text { ESJI (KZ) } \\
\text { SJIF (Morocco) }\end{array}$ & $\begin{array}{l}=0.912 \\
=\mathbf{0 . 2 0 7} \\
=\mathbf{3 . 8 6 0} \\
=\mathbf{2 . 0 3 1}\end{array}$ & $\begin{array}{l}\text { ICV (Poland) } \\
\text { PIF (India) } \\
\text { IBI (India) }\end{array}$ & $\begin{array}{l}=6.630 \\
=1.940 \\
=4.260\end{array}$ \\
\hline
\end{tabular}

high levels of pensions in the Chukotskiy autonomous okrug, Kamchatskiy Krai and Sakhalinskaya oblast - a high average monthly nominal wage.

Comparison of data on average monthly wages, the number of employees and the level of pensions provide a conclusion that the lowest rootedness of the population is observed in the Evreyskaya autonomous oblast, and potentially high in the Primorskiy Krai.

As noted by Motrich [4] "... in the subjects of the Far East Federal District, the social welfare index is significantly inferior to the maximum value fixed for Moscow. In all regions of the region, the index of social welfare is decreasing" 1 Another, this time encouraging phenomenon is that the FEFD is one of four districts where there is a natural increase in the population. The program "Far Eastern hectare" could also help to rectify the situation, however, since allocation of land is carried out in hard-to-reach areas, in the absence of communications, we do not believe that this project will seriously change the demographic situation in the region [1]. As Ryazantseva notes [8] At the same time, among the nine constituent entities of the Russian Federation that form the Far Eastern Federal District, only four values of per capita GRP exceed the average for this district, while in the remaining five subjects (the Evreyskaya autonomous oblast, the Amurskaya oblast, the Primorskiy Krai, the Khabarovskiy Kray, Chukotskiy autonomous okrug) - GRP per capita below the average on the Far Eastern Federal District.

\section{Conclusion}

The deterioration of the social and transport infrastructure does not contribute to the growth of the region's attractiveness for living and employment. Considering the fact that the urban population exceeds the rural population by three times the average for Russia, the concentration of the population in the large cities of the Far Eastern Federal District and the outflow from the rural areas will continue.

The provision of labor resources can be the most serious test for the organization of the territories of advanced development, since their absence will force the owners of enterprises residents of the TPD to attract migrants, which calls into question the fulfillment of one of the main goals of creating TPD - ensuring accelerated socioeconomic development and creating comfortable

${ }^{1}$ It is calculated by dividing the relative per capita income in the region by the Gini coefficient; it is higher the higher the real incomes of the population and the lower the degree of stratification of society in comparison with the situation in the whole country. conditions for maintenance of ability to live of the population. 


\begin{tabular}{l|lr|ll|ll} 
& ISRA (India) & $=\mathbf{1 . 3 4 4}$ & SIS (USA) & $=\mathbf{0 . 9 1 2}$ & ICV (Poland) & $=\mathbf{6 . 6 3 0}$ \\
Impact Factor: & ISI (Dubai, UAE) $=\mathbf{0 . 8 2 9}$ & PUHL (Russia) $=\mathbf{0 . 2 0 7}$ & PIF (India) & $=\mathbf{1 . 9 4 0}$ \\
& GIF (Australia) & $\mathbf{0 . 5 6 4}$ & ESJI (KZ) & $=\mathbf{3 . 8 6 0}$ & IBI (India) & $\mathbf{4 . 2 6 0}$ \\
& JIF & $\mathbf{1 . 5 0 0}$ & SJIF (Morocco) & $=\mathbf{2 . 0 3 1}$ & & \\
\hline
\end{tabular}

\section{References:}

1. Buhval'd E.M., Valentik O.N. (2015) Territorii operezhajushhego razvitija: padenie ili illjuzija? // JeTAP: jekonomicheskaja teorija, analiz, praktika. 2015. № 2. - p. 72-84.

2. Zel'dner A.G., Osipov V.S. (2016) Disfunkcii sistemy gosudarstvennogo upravlenija V social'noj sfere // CITISJe. 2016. № 4 (8). - p. 3.

3. Zel'dner A.G., Osipov V.S. (2016) Prioritety v jekonomicheskoj politike gosudarstva (teorija i praktika) // Jekonomicheskie strategii. 2016. T. 18. № 7 (141). - p. 38-49.

4. Motrich E.M. (2015) Sovremennye osobennosti vosproizvodstva naselenija v Dal'nevostochnom federal'nom okruge // Izvestija DVFU. Jekonomika i upravlenie. 2015. №3. - p. 59.

5. Osipov V.S. (2016) Strategicheskoe znachenie territorij operezhajushhego razvitija dlja jekonomiki strany // Vestnik Moskovskogo universiteta im. S.Ju. Vitte. Serija 1: Jekonomika i upravlenie. 2016. № 4 (19). -p. 512.

6. Osipov V.S. (2016) Territorii operezhajushhego razvitija - novyj vektor institucional'nyh uslovij razvitija rossijskoj promyshlennosti // Jekonomika i predprinimatel'stvo. 2016. № 9 (74). - p. 852-857.

7. Osipov V.S., Zel'dner A.G. (2016) Territorii operezhajushhego razvitija: institucionalizacija regional'nogo jekonomicheskogo razvitija. M., 2016.

8. Rjazanceva M.V. (2015) Stimulirovanie pritoka trudovyh resursov na territorii operezhajushhego social'no-jekonomicheskogo razvitija Dal'nego Vostoka // Rossijskoe predprinimatel'stvo. 2015. T. 16. № 18. - p. 3091-3102.

9. Skryl' T.V. (2016) Mehanizm territorij operezhajushhego razvitija kak jelement ustojchivogo jekonomicheskogo razvitija // Jekonomika obrazovanija. 2016. № 2 (93). - p. 135-147.

10. Charkina E.S. (2015) K voprosu ob operezhajushhem social'no-jekonomicheskom razvitii otdel'nyh territorij regionov Rossii // Upravlencheskoe konsul'tirovanie. 2015. № 9 (81). -p. 105-111. 